\title{
Urethral Cancer Clinical TNM Finding v7
}

National Cancer Institute

\section{Source}

National Cancer Institute. Urethral Cancer Clinical TNM Finding v7. NCI Thesaurus. Code C89392.

A clinical finding about one or more characteristics of urethral cancer, following the rules of the TNM AJCC V7 classification system. 